\title{
Haemodynamic Augmentation in the Treatment of Vasospasm in Aneurysmal Subarachnoid Hemorrhage
}

\author{
Anevrizmal Subaraknoid Kanamaya Bağlı Vazospazmnn Tedavisinde \\ Hemodinamik Destek
}

\author{
Melek GURA ${ }^{1}$, Ilhan ELMACI ${ }^{3}$, Ajlan CERCI $^{2}$, Esra SAGIROGLU ${ }^{1}$, K. Kenan COSKUN ${ }^{2}$ \\ ${ }^{1}$ M.H. Istanbul Medeniyet University, Goztepe Education and Research Hospital, Department of Anesthesiology and Reanimation, \\ Istanbul, Turkey \\ ${ }^{2}$ M.H. Istanbul Medeniyet University, Goztepe Education and Research Hospital, Department of Neurosurgery, Istanbul, Turkey \\ ${ }^{3}$ Acibadem University, Faculty of Medicine, Department of Neurosurgery, Istanbul, Turkey
}

Correspondence address: Melek GURA / E-mail: melekgura@gmail.com

\begin{abstract}
AIM: Hypertension, hypervolemia and hemodilution therapy is a common approach to cerebral vasospasm after subarachnoid haemorrhage. This study is designed to see the difference of moderate or aggressive hypervolemia supported with induced hypertension in symptomatic vasospasm detected with transcranial Doppler ultrasonography (TCD) measurements.

MATERIAL and METHODS: Fifty eight patients who had aneurysm clipping and were admitted to the neurointensive care unit were treated with normovolemia and induced hypertension $(n=35)$ or hypervolemia supported with induced hypertension $(n=23)$ targeting a mean arterial pressure of $110-130 \mathrm{~mm} \mathrm{Hg}$ and central venous pressure of 8-12 mm Hg. Daily TCD, fluid intake, fluid balance and haemodynamic values were recorded for 14 days.

RESULTS: There were no differences detected in mean arterial pressure, central venous pressure, hematocrit values, fluid balance and middle cerebral artery flow velocities between the two groups through 14 days $(p>0.05)$. Hyponatremia, pulmonary edema and cerebral ischemia were observed as complications.
\end{abstract}

CONCLUSION: Hypervolemia adds no benefit compared to normovolemia in the treatment of vasospasm occurred as a result of subarachnoid hemorrhage. Induced hypertension establishes the haemodynamic augmentation to prevent and treat vasospasm.

KEYWORDS: Aneurysmal subarachnoid hemorrhage, Cerebral vasospasm, Hypertension, Hypervolemia

öz

AMAÇ: Subaraknoid kanamaya bağlı gelişen vasospasm tedavisinde hipertansiyon, hipervolemi ve hemodilüsyon tedavisi yaygın bir yaklaşımdır. Bu çalışma, transkranyal Doppler ultrasonografi ölçümleri ile saptanan semptomatik vasospasm durumlarında hipertansiyon ile desteklenen hafif veya agresif hipervoleminin farkını görmek için düzenlenmiştir.

YÖNTEM ve GEREÇLER: Anevrizmaları kliplenen ve nöroyoğun bakım ünitesinde takip edilen 58 hastaya normovolemi ve hipertansiyon ( $\mathrm{n}=35$ ) ve hipervolemi ve hipertansiyon ( $\mathrm{n}=23$ ) uygulanarak 110-130 mmHg ortalama arter basıncı, 8-12 mmHg santral venöz basınç hedeflendi. TCD, sıvı alımı ve hemodinamik değerler kaydedildi.

BULGULAR: On dört gün boyunca takip edilen ortalama arter basıncı, santral venöz basınç, hematokrit değerleri, sıvı dengesi ve orta serebral arter akım hızlarında iki grup arasında fark yoktu. Komplikasyon olarak hiponatremi, pulmoner ödem ve serebral iskemi kaydedildi.

SONUÇ: Subaraknoid kanama sonucu ortaya çıkan vasospasmın tedavisinde normovolemi ile karşılaştııılığında hipervolemi ek bir yarar sunmamaktadır. Hipertansiyon vasospasmı önlemek ve tedavi etmek için gereken hemodinamik desteği sağlamaktadır.

ANAHTAR SÖZCÜKLER: Anevrizmal subaraknoid kanama, Hipertansiyon, Hipervolemi, Serebral vasospazm

\section{INTRODUCTION}

Hyperdynamic therapy with hypervolemia, hypertension and hemodilution is used in many institutions for prophylaxis and treatment of symptomatic vasospasm. Vasospasm needs to be predicted and prevented due to neurologic complications. $(3,10)$. However, the argument is still going on about the indication, modality, degree and risk/benefit ratio of triple $\mathrm{H}$ therapy $(17,24,29)$. The goal of triple $\mathrm{H}$ therapy in aneurysmal subarachnoid hemorrhage (SAH) is to manipulate circulating volume with volume expansion, blood pressure augmentation, assure oxygenation and blood viscosity to enhance cerebral blood flow in the setting of vasoconstriction $(17,35)$. TCD offers an easy method for patients with SAH to detect the elevated flow velocities in basal cerebral arteries and identify the patients at risk of neurological deficits due to vasospasm (31). Although some investigators advocate volume expansion for the treatment of vasospasm, the data about volume expansion is inconclusive in the literature. The 
present study is postulated to compare induced hypertension and moderate hypervolemia with induced hypertension and aggressive hypervolemia on cerebral blood flow velocities focusing on the efficacy of triple $\mathrm{H}$ therapy.

\section{MATERIAL and METHODS}

The study was performed in the neurointensive care unit of Goztepe Training Hospital in a period of two years (20072009). With the approval of institutional review board and after obtaining informed consents, a retrospective and prospective study of 58 patients with $\mathrm{SAH}$ who had developed vasospasm postoperatively was conducted. The exclusion criteria were traumatic and nonaneurysmal $\mathrm{SAH}$, aneurysmal $\mathrm{SAH}$ with no symptoms of vasospasm, congestive heart failure and renal insufficiency. The aneurysmal SAH was documented by cranial tomography (CT) and angiography in all patients. Whenever possible, the patients had surgery to clip the ruptured aneurysm before SAH day 3. Hunt Hess classification, Fisher grade and Glasgow Coma Scale and Glasgow Outcome Scale (3 months) of the patients were recorded $(6,9,11,33)$.

Perioperative management of the patients were performed according to a standard treatment protocol. Central and arterial catheters were placed at the time of surgery. Mannitol $(1 \mathrm{~g} / \mathrm{kg}$ ) was used during the surgery for brain relaxation and standard microsurgical techniques were used to clip the aneurysm. Preoperative and postoperative TCD findings (middle cerebral artery flow velocities (MCAmFV) $>120 \mathrm{~cm} / \mathrm{s}$ ), the neurosurgeon's report during the operation and the patient's neurological deterioration (level of consciousness, confusion, focal deficits) helped to predict vasospasm and begin the therapy. After admission to neurointensive care unit, all patients had neurological evaluation hourly and TCD measurements every day. In 58 patients, a mean arterial pressure (MAP) of 110-130 mm Hg were targeted and when the targeted MAP values were not reached, dopamine and norepinephrine were administered. Hypertensive hypervolemic therapy (HHT) was conducted in the first 23 patients, who were evaluated retrospectively. Thirty-five patients were treated with normovolemia and induced hypertension (HNT) and assessed prospectively. Saline $0.9 \%$ and human albumin 5\% (250 $\mathrm{ml} / 6 \mathrm{hr}$ ) were administered for 14 days. During the follow up period of 14 days, MAP, central venous pressure, hematocrit, insulin requirement, MCAmFV and 24 hour fluid intake and fluid balance and outcome were evaluated. Besides fluid therapy, antibiotics, steroids, stress ulcer prophylaxis and analgesics were given. Euglycemia, eucapnia and normothermia were maintained. Insulin infusion was performed when blood glucose levels exceeded $110 \mathrm{mg} / \mathrm{dl}$. The daily TCD measurements were conducted transtemporally using a traditional $2 \mathrm{MHz}$ transducer (DWL). The depth and angle of insonation giving the highest MCA flow velocity was chosen. Daily TCD mFV measurements of MCA were made by the same investigator bilaterally. Complications were defined and recorded as follows; focal deficit, deterioration in level of consciousness, infarction on a CT scan, symptomatic hydrocephalus, seizures, cerebral edema, electrolyte disorder, hyperglycemia, arrhythmia, pulmonary edema and congestive heart failure.

The statistical analysis was performed in SPSS 15.0 for Windows for data processing and analysis. The definitive

Table I: Demographic and Clinical Data of the Patients

\begin{tabular}{|c|c|c|c|c|}
\hline \multirow{2}{*}{\multicolumn{2}{|c|}{ age (vear) }} & HNT $(n=35)$ & HHT $(n=23)$ & $\mathbf{p}$ \\
\hline & & $56.34 \pm 13.36$ & $52.78 \pm 10.93$ & 0.369 \\
\hline \multicolumn{2}{|c|}{ gender (male/female) } & $15 / 20$ & $14 / 9$ & \\
\hline \multicolumn{2}{|c|}{ GCS } & $10.97 \pm 4.85$ & $11.78 \pm 4.42$ & 0.860 \\
\hline \multicolumn{2}{|l|}{ CVP $(\mathrm{mmHg})$} & $7.03 \pm 2.35$ & $8.13 \pm 1.36$ & 0.058 \\
\hline \multicolumn{2}{|l|}{$\mathrm{MAP}(\mathrm{mmHg})$} & $99.52 \pm 17.40$ & $95.54 \pm 14.88$ & 0.738 \\
\hline \multicolumn{2}{|l|}{ glucose (g/dl) } & $135.91 \pm 25.47$ & $136.83 \pm 27.04$ & 0.905 \\
\hline \multicolumn{2}{|l|}{ iv. insülin inf. } & $14 / 35$ & $7 / 23$ & 0.458 \\
\hline Fisher's Grade & $\begin{array}{l}\text { I } \\
\text { II-III }\end{array}$ & $\begin{array}{l}16 \\
19\end{array}$ & $\begin{array}{l}10 \\
13\end{array}$ & 0.867 \\
\hline Hunt Hess Class. & $\begin{array}{l}\text { I, II, III } \\
\text { IV, V }\end{array}$ & $\begin{array}{r}25 \\
8\end{array}$ & $\begin{array}{r}21 \\
2\end{array}$ & 0.135 \\
\hline \multicolumn{2}{|l|}{ GOS (3-5) } & $15 / 35$ & $10 / 23$ & 0.963 \\
\hline Aneurysm location & $\begin{array}{l}\text { ACom.A } \\
\text { PCA } \\
\text { ICA } \\
\text { MCA }\end{array}$ & $\begin{array}{r}14 \\
1 \\
4 \\
8\end{array}$ & $\begin{array}{l}8 \\
3 \\
3 \\
7\end{array}$ & \\
\hline
\end{tabular}

HNT, hypertensive normovolemia therapy; HHT, hypertensive hypervolemia therapy; GCS, Glasgow Coma Scale; CVP, central venous pressure; MAP, mean arterial pressure; GOS, Glasgow Outcome Scale; ACA, anterior commucican artery; PCA, posterior commucican artery; ICA, internal commucican artery; MCA, middle commucican artery. 
analysis was used for mean, standard deviation, minimum and maximum variables. Chi-Square test was used for the comparison between the two groups. Continuous variables were compared with 2-tailed t test and the significance level was recorded as $p<0.05$.

\section{RESULTS}

Fifty-eight SAH patients were treated to overcome vasospasm and followed up during 14 days. The details about age, gender, GCS, Hunt-Hess classification, Fisher Grade and location of the aneurysm are in Table I.

There was no difference between the two groups when compared according to GCS, Fisher Grade, Hunt-Hess classification, insulin requirement, CVP and outcome ( $p>$ 0.05) (Table I).

Compared with HNT group, HHT patients had a significantly higher fluid intake in 24 hours $(p<0.05)$ but no difference in fluid balance was detected ( $p>0.05$ ) (Figures 1, 2).

Through the study period of 14 days, with the induced hypertension, there was no difference observed in MAP measurements (Figure 3). Mean values of everyday measurements of MCA mFV of the two groups in 14 days presented significance in the first five days but there was no difference in the following days (Figure 4).

$\mathrm{Hct}$ recordings presented no distinction in the mean values (Figure 5).

There were no differences in the frequency of the complications. Dilutional hyponatremia (< $135 \mathrm{mEq} / \mathrm{L})$ occurred in only 3 patients and pulmonary edema in one patient in HHT. Infarction on CT scan was observed in 5 patients in HHT group and 4 patients in HNT group.

\section{DISCUSSION}

Cerebral vasospasm is the delayed narrowing of large capacitance arteries of the base of the brain after $\mathrm{SAH}$ (1). It is the most common cause of morbidity and mortality following $\mathrm{SAH}$, as it occurs in a delayed fashion, it should be prevented and treated with aggressive strategies $(10,12,13,17,21,28,37)$. Triple $\mathrm{H}$ therapy is being utilized for prophylaxis and treatment of vasospasm and stroke complicating $\mathrm{SAH}$ and it is stated that this approach may decrease mortality and morbidity (level of evidence Ila, Grade B recommendation) (1,29).

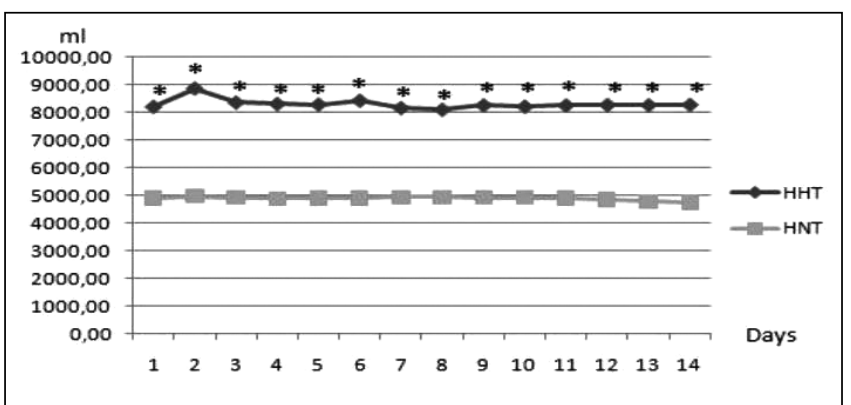

Figure 1: Plots demonstrating mean fluid intake for the two groups during 14 days.
The first step is to maintain adequate volume status because the patient is hypovolemic due to aneurysmal bleeding and hypothalamic dysfunction and secretion of natriuretic peptides(34). But, most of the literature suggests that

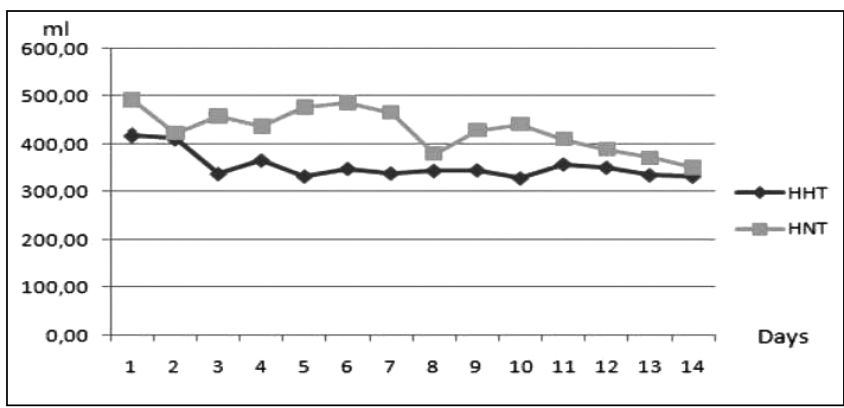

Figure 2: Plots demonstrating mean fluid balance for the two groups during 14 days.

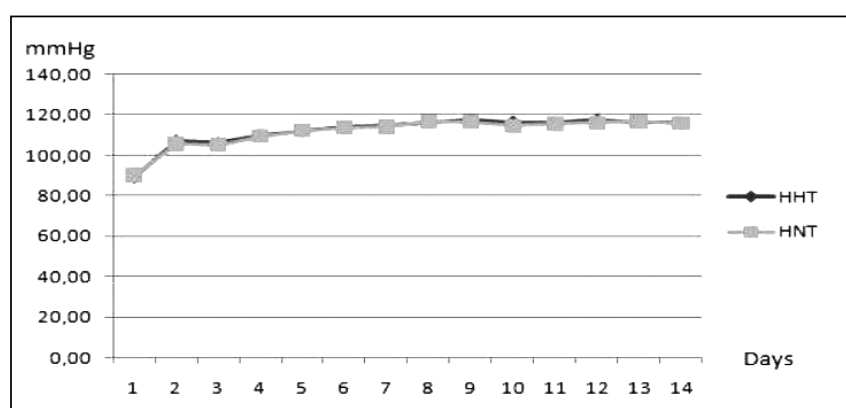

Figure 3: Plots demonstrating mean arterial pressures for the two groups during 14 days.

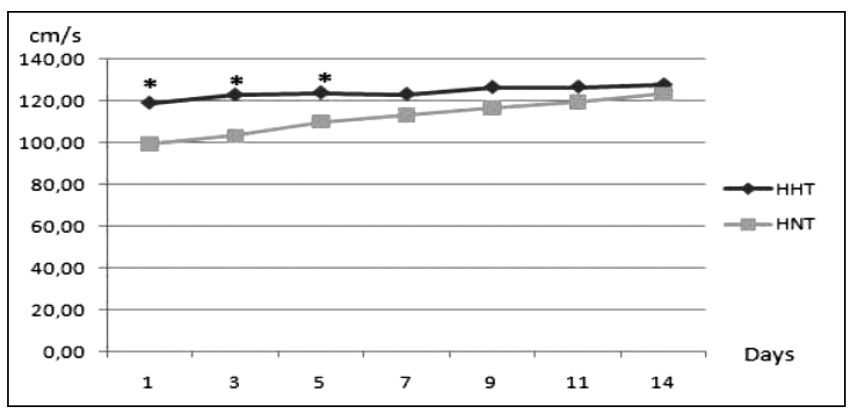

Figure 4: Plots demonstrating the MCA mFV values of the two groups through 14 days.

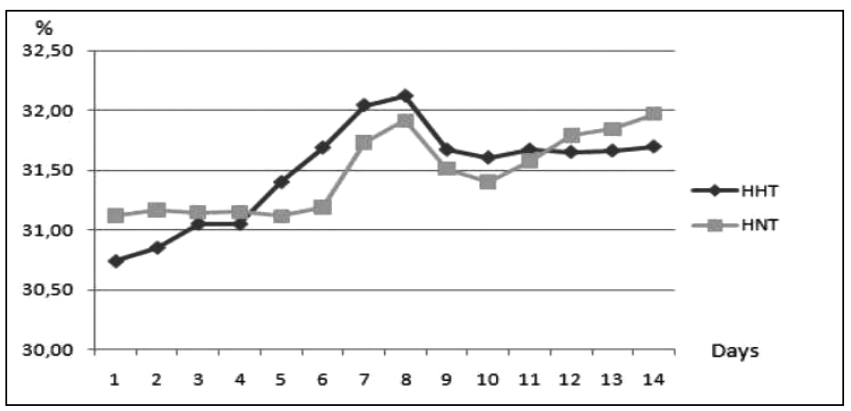

Figure 5: Plots demonstrating hematocrit values for the two groups during 14 days. 
hypervolemia is not really achieved to change the cerebral blood flow, in addition it has many side effects and the benefits of hypervolemia are not detailed $(14,29,35)$.

Even though the components of triple-H therapy aim to increase cerebral perfusion and as a result improve the outcome, there have been a few randomized clinical trials on the effectiveness of triple-H therapy. In the systematic review of Dankabaar et al. isovolemic hemodilution or hypervolemia do not seem to improve cerebral blood flow but induced hypertension alone or with hypervolemia have improved cerebral blood flow in some studies (2).

Gupta et al. have studied on 25 patients with $\mathrm{SAH}$ to whom they performed triple-H therapy. They have started triple-H after detection of vasospasm with TCD recordings. Hypokalemia, haemorrhagic infarct, septicemia have occurred as complications. They have concluded that triple- $\mathrm{H}$ therapy is useful in vasospasm induced ischemic deficits, but in the presence of acute infarcts, it worsens brain edema; and in addition, intracranial pressure monitoring is advised in order to evaluate the components of triple-H therapy (7).

Despite the widespread use of triple $\mathrm{H}$ therapy to prevent vasospasm after $\mathrm{SAH}$, only a few studies have questioned its efficacy and there is insufficient data of evidence based medicine to make recommendations for the preventive use of triple $\mathrm{H}$ therapy in SAH patients $(26,36)$.

In a study of $82 \mathrm{SAH}$ patients treated with hypervolemia or normovolemia, even though the cardiac filling pressures and fluid intake were higher in hypervolemia group, increase in blood volume or cerebral blood flow measurements have not presented any difference between the two groups (14).

Raabe et al. investigated the effects of hypervolemia and hypertension on brain tissue oxygenation in $45 \mathrm{SAH}$ patients. Moderate hypertension caused the highest increase in brain tissue oxygenation (90\%) with the lowest rate of complications, where aggressive hypervolemic hypertension treatment increased brain tissue oxygenation $60 \%$ and hypervolemia resulted with highest risk and lowest benefit for the patients (24).

Muench et al. investigated the effects of triple $\mathrm{H}$ therapy, regarding the results on regional blood flow, intracranial pressure and brain tissue oxygenation in animals and patients who experienced SAH. Vasopressors and colloids were used to establish the three components of triple $\mathrm{H}$ therapy. They observed that regional cerebral blood flow improved with induced hypertension and hypervolemia but further increases of cerebral blood flow did not lead to an improvement in brain tissue oxygenation compared to induced hypertension alone. That is, the oxygen carrying capacity diminishes as Hct levels decline with hypervolemia, and hypervolemia should be applied with caution due to increased risk of complications (18).

In the study of Mocco et al, fluids were used to achieve volume expansion and increase cardiac output. The increase in cardiac output is expected to increase the blood pressure and CBF. Hypertension will be achieved with volume expansion but vasoactive drugs may be used also for the targeted levels (17).

In a study of $28 \mathrm{SAH}$ patients of Manno et al. hypertension was induced with phenylephrine. In the majority of the patients with disturbed autoregulation, TCD velocities were altered by the manipulation of blood pressure (15).

Following $\mathrm{SAH}$, the blood pressure augmentation is disrupted and cerebral blood pressure becomes pressure oriented. In a study, systolic blood pressure was augmented with dopamine and subcutaneous vasopressin to levels between 150-175 $\mathrm{mm} \mathrm{Hg}$ and cerebral blood flow and outcome have improved (34).

In the observational study using microdialysis and brain oxygen monitoring, it was demonstrated that a hemoglobin concentration lower than $9 \mathrm{gr} / \mathrm{dl}$ is associated with brain hypoxia and cell energy dysfunction in patients with poor grade aneurysmal SAH (20).

Several authors have reported complications in 10-20\% of the patients treated with triple $\mathrm{H}$ therapy. Performing triple $\mathrm{H}$ therapy should take into account the potential risks such as pulmonary oedema (17\%), myocardial ischemia, dilutional hyponatremia (3\%), renal medullary washout, catheterrelated complications and cerebral oedema $(4,13,29,36,38)$.

TCD has the advantage of detecting elevated flow velocities in the basal cerebral arteries in risk of vasospasm and delayed neurological deficits. The sensitivity of TCD for clinical vasospasm detection was investigated as good as angiography in the study of Suarez et al. High mean cerebral blood flow velocities could be apparent before the presence of symptomatic vasospasm and daily TCD ultrasound monitoring could provide early identification of patients at risk of vasospasm. It is postulated that the mean velocity of more than $120 \mathrm{~cm} / \mathrm{s}$ as a lower limit indicates vasospasm $(4,7,8,12,14,19,27,30,31,32)$.

McGirt et al. showed that in $70 \%$ of SAH patients, TCD could detect vasospasm on average 2.5 days before the onset of neurological deficits (16).TCD may be useful to follow vasospasm progression, giving the chance for prophylactic treatment and guide the therapy employed for vasospasm (25).

\section{The study findings}

In the present study, triple $\mathrm{H}$ therapy was aimed to treat vasospasm in SAH patients. In order to reach the targeted values of mean arterial pressure in the first 23 patients, vasopressors were required extremely to support the hypervolemic therapy. Following the observation of 23 patients, the study was designed as a retrospective and a prospective one, to evaluate the effects of hypervolemia and normovolemia with induced hypertension. The main goal of hypervolemia was to increase the blood pressure. In the hypervolemia group, the mean fluid intake was $8105 \pm$ 399.12 and there was a significant difference between the 
two groups (Figure 1). However, the balance of fluid input and output was similar in all patients (Figure 2). In cases of MAP less than $110 \mathrm{~mm} \mathrm{Hg}$, dopamine and norephinephrine were administered and the targeted MAP values were reached in both groups with no significant difference (Figure 3).

After the evaluation of 58 patients, there was no difference found between HNT and HHT induced to prevent and treat vasospasm in SAH patients. The goal of triple $\mathrm{H}$ therapy could be achieved with higher efficacy and fewer complications by using catecholamines. Patients treated with normovolemia and hypertension or hypervolemia and hypertension yielded the similar improvements in MCA flow velocities also (Figure 4) However, with minor risks, induced hypertension increases peripheral resistance and as a result MCA flow velocities could decrease.

Aggressive hypervolemia treatment may help to increase flow velocities and manage vasospasm, however, risk-benefit ratio is questionable and the decision to use hypervolemia should be based on the clinical situation of the patient. That is, hypervolemia should be employed on the individualised basis. It has intracranial and extracranial complications, in the study population three patients presented hyponatremia and one patient had to be treated for pulmonary edema. Cerebral ischemia was detected in CT scans of $5 \mathrm{HHT}$ patients and 4 HNT patients. Hypervolemia is maintained with colloids, low molecular weight dextran, blood, albumin and hetastarch. In this study albumin 5\% was infused to obtain volume expansion and blood transfusion was not performed with Hct values greater than $30 \%$. In our results, there was no difference in hemodilution between the groups (Figure 5). Hyperglycemia is accepted as a risk factor for outcome in $\mathrm{SAH}$ patients. The number of patients requiring insulin infusion for hyperglycemia management was similar in both groups. In the means of GOS observed after 3 months, there was not difference between hypervolemia or normovolemia treated patients (Table I).

The limitation of this study is that it is designed as a retrospective and prospective study without randomization of the patients. The protocol performed for SAH patients was hypervolemia and hypertension; however, the treatment protocol performed consisted complications of hyponatremia in three patients and pulmonary edema in one patient. Hypertension could not be attained with hypervolemia; induced hypertension was required in most of the patients. In the rest of the patients, normovolemia and induced hypertension were performed. In our patient population they had no cardiac or pulmonary diseases so CVP catheters were inserted instead of Swan Ganz catheters. Although the study started with the three components of triple-H therapy, administration of high volumes seemed not to make any difference in outcome and symptomatic vasospasm and in the rest of the patients, normovolemia was aimed.

Although we used CT scans and TCD ultrasonography to exclude other causes of neurologic deterioration, angiography was not performed to confirm a diagnosis of vasospasm.
However, several studies reported a specificity of $98 \%$ to 100 $\%$ and sensitivity of $58 \%$ to $85 \%$ for detection of angiographic vasospasm by TCD ultrasonography $(8,23)$.

\section{CONCLUSION}

Hypervolemia treatment may be associated with complications. More studies are needed to determine the risk-benefit ratio of hypervolemia. Normovolemia and hypertension may be an effective method to overcome vasospasm in SAH, especially in patients where the autoregulation is not preserved.

\section{REFERENCES}

1. Bederson JB, Connolly ES Jr, Batjer HH, Dacey RG, Dion JE, Diringer MN, Duldner JE Jr, Harbaugh RE, Patel $A B$, Rosenwasser RH: American Heart Association: Guidelines for the management of aneurysmal subarachnoid hemorrhage: A statement for healthcare professionals from a special writing group of the stroke council, Stroke 40:994-1025, 2009

2. Dankbaar JW, Slooter AJ, Rinkel GJ, Schaaf IC: Effect of different component of triple-H therapy on cerebral perfusion in patients with aneurysmal subarachnoid hemorrhage: $A$ systematic review. Crit Care 14:R23, 2010

3. Diringer MN: Management of aneurysmal subarachnoid hemorrhage. Crit Care Med 37:432-440, 2009

4. Egge A, Waterloo $K$, Sjøholm $H$, Solberg $T$, Ingebrigtsen $\mathrm{T}$, Romner B: Prophylactic hyperdynamic postoperative fluid therapy after aneurysmal subarachnoid hemorrhage: A clinical, prospective, randomized, controlled study. Neurosurgery 49:593-606, 2001

5. Ekelund A, Saveland H, Romner B, Brandt L: Trancranial doppler ultrasound in hypertensive versus normotensive patients after aneurysmal subarachnoid hemorrhage. Stroke 26:2071-2074, 1995

6. Fisher C, Kistler J, Davis J: Relation of cerebral vasospasm to subarchnoid hemorrhage visualized by computerized tomographic scanning. Neurosurgery 6:1-9, 1980

7. Gupta D, Sharma BS, Gupta SK, Bapuraj R, Khosla VK: Postoperative hypertensive-hypervolaemic-haemodilution (triple $\mathrm{H}$ ) therapy in the treatment of vasospasm following aneurysmal subarachnoid haemorrhage. Neurol India 48: 126-131, 2000

8. Harrod CG, Bendok BR, Batjer HH: Prediction of cerebral vasospasm in patients presenting with aneurysmal subarachnoid hemorrhage: A review. Neurosurgery 56: 633-654, 2005

9. Hunt $W E$, Hess RM: Surgical risk as related to time of intervention in the repair of intracranial aneurysms. J Neurosurg 28:14-20, 1968

10. Janjua N, Mayer SA: Cerebral vasospasm after subarachnoid haemorrhage. Curr Opin Crit Care 9:113-119, 2003

11. Jennett $B$, Bond $M$ : Assessment of outcome after severe brain damage. Lancet 1: 480-484, 1975

12. Keyrouz SG, Diringer MN: Clinical review: Prevention and therapy of vasospasm in subarachnoid haemorrhage. Crit Care 11:220, 2007 
13. Lee KH, Lukovits T, Friedman JA:'Triple-H'Therapy for cerebral vasospasm following subarachnoid hemorrhage. Neurocrit Care 4:68-76, 2006

14. Lennihan L, Mayer SA, Fink ME, Beckford A, Paik MC, Zhang H, Wu YC, Klebanoff LM, Raps EC, Solomon RA: Effect of hypervolemic therapy on cerebral blood flow after subarachnoid hemorrhage. Stroke 31:383-391, 2000

15. Manno EM, Gress DR, Schwamm LH, Diringer MN, Ogilvy CS: Effects of induced hypertension on transcranial doppler ultrasound velocities in patients after subarachnoid hemorrhage. Stroke 29:422-428, 1998

16. McGirt MJ, Blessing RP, Goldstein LB: Transcranial Doppler monitoring and clinical decision making after subarachnoid hemorrhage. J Stroke Cerebrovasc Dis 12:88-92, 2003

17. Mocco J, Zacharia BE, Komotar RJ, Connolly ES Jr: A review of current and future medical therapies for cerebral vasospasm following aneurysmal subarachnoid hemorrhage. Neurosurg Focus 21:E9, 2006

18. Muench $E$, Horn $P$, Bauhuf $C$, Roth $H$, Philipps $M$, Hermann $P$, Quintel M, Schmiedek P, Vajkoczy P: Effects of hypervolemia and hypertension on regional cerebral blood flow, intracranial pressure and brain tissue oxygenation after subarachnoid hemorrhage. Crit Care Med 35:1844-1851, 2007

19. Martin NA, Thomas KM, Caron M: Transcranial dopplertechniques, application, and instrumentation, Neurosurgery online volume 33(4):761-763,1993

20. Oddo M, Milby A, Chen I, Frangos S, MacMurtrie E, MaloneyWilensky E, Stiefel M, Kofke A, Levine J, Le Roux PD: Hemoglobin concentration and cerebral metabolism in patients with aneurysmal subarachnoid hemorrhage. Stroke 40;1275-1281, 2009

21. Priebe $\mathrm{H}$ J: Aneurysmal subarachnoid haemorrhage and the anaesthetist. Br J Anaest 99:102-118, 2007

22. Qureshi A,Sung G, Razumovsky A, Lane K, Straw R, Ulatowski $\mathrm{J}$ : Early identification of patients at risk for symptomatic vasospasm after aneurysmal subarachnoid hemorrhage, Crit Care Med 28:984-990, 2000

23. Raabe A, Beck J, Keller M, Vatter H, Zimmermann M, Seifert $\mathrm{V}$ : Relative importance of hypertension compared with hypervolemia for increasing cerebral oxygenation in patients with cerebral vasopasm after subarachnoid hemorrhage. J Neurosurg 103:974-981, 2005

24. Rigamonti A, Ackery A, Baker AJ: Transcranial doppler monitoring in subarachnoid haemorrhage: A critical tool in critical care. Can J Anaesth 55:112-123, 2008
25. Rinkel GJE, Feigin V L, Algra A, Van Gjin J: Hypervolemia in aneurysmal subarachnoid hemorrhage. Stroke 36:1104-1105, 2005

26. Saqqur M, Zygun D, Demchuk A: Role of transcranial doppler in neurocritical care. Crit Care Med 35:216-223, 2007

27. Segal E, Greenlee JD, Hata SJ, Perel A: Monitoring intravascular volumes to direct hypertensive, hypervolemic therapy in a patient with vasospasm. J Neurosurg Anesthesiol 16:296-298, 2004

28. Sen J, Belli A, Albon H, Morgan L, Petzold A, Kitchen N: Triple-H Therapy in the management of subarachnoid hemorrhage. Lancet Neurol 2:614-621, 2003

29. Sorteberg A, Sorteberg W: Transcranial doppler ultrasonography: Part 2:basic principles and applications in neurosurgery, Contemporary Neurosurgery 29(6):1-7, 2007

30. Springborg, J, Frederiksen HJ, Eskesen V, Olsen NV: Trends in monitoring patients with aneurysmal subarachnoid haemorrhage. Br J Anaesth 94:259-270, 2005

31. Suarez Jl, Qureshi Al, Yahia AB, Parekh PD, Tamargo RJ, Williams MA, Ulatowski JA, Hanley DF, Razumovsky AY: Symptomatic vasospasm diagnosis after subarachnoid hemorrhage: Evaluation of transcranial doppler ultrasound and cerebral angiography as related to compromised vascular distribution. Crit Care Med 30:1348-1355, 2002

32. Teasdale G, Jennett B: Assessment of coma and impaired consciousness. A practical scale. Lancet 2:81-84, 1974

33. Treggiari MM, Deem S: Which $\mathrm{H}$ is the most important in triple-H therapy for cerebral vasospasm? Curr Opin Crit Care 15:83-86, 2009

34. Treggiari-Venzi MM, Suter PM, Romand JA: Review of medical prevention of vasospasm after aneurysmal subarachnoid haemorrhage: A problem of neurointensive care. Neurosurgery 48:249-262, 2001

35. Treggiari MM, Walder B, Suter PM, Romand JA: Systematic review of the prevention of delayed ischemic neurological deficits with hypertension-hypervolemia-hemodilution therapy following subarachnoid hemorrhage. J Neurosurg 98: 978-984, 2003

36. Vora Y, Suarez-Almazor M, Steinke D, Martin M, Findlay M: Role of transcranial doppler monitoring in the diagnosis of cerebral vasospasm after subarachnoid hemorrhage. Neurosurgery 44:1237-1247, 1999

37. Weyer G, Nolan C, Macdonald L: Evidence-based cerebral vasospasm management. Neurosurg Focus 21:E8, 2006 